or of the remodelling of living material". In this and subsequent volumes they hope to "encourage the synthesis of some much-needed general ideas about mechanisms of development" and to "discourage the proliferation of clones of scientific thought". They hope to do this by publishing various kinds of review articles, giving authors, to judge from this first volume, space enough adequately to develop these general ideas.

There is always a danger in reviews of a lack of detail, and that those most interested know all about it anyway. The papers in this volume are generally successful in riding these dangers. It would be surprising if at least some of the essays did not provide food for thought for most morphogeneticists. The articles will also commend themselves to advanced students in the subject, for whom there has been insufficient reading matter of this kind.

The contributions to this volume range from a consideration of the structural and dynamic aspects of development of the teleost egg (Ch. Devillers), the embryology of ascidians (G. Reverberi), and the problem of the organizer from the chemical point of view (T. Tamada); through the morphogenesis of the eye (G. V. Lopashov and O. G. Stroeva) and limb (Edgar Zwilling), and regeneration of appendages (R. J. Goss) in vertebrates; to a rather less embryological approach in the differentiation of vertebrate pigment cells (C. E. Wilde), the action of morphostatic substances and the role of proteases in regenerating tissues and tumour cells (F. G. Lehmann), and determining factors in cell growth in relation to morphogenesis in plants (F. C. Steward and H. Y. Mohan Ram). It is not possible to comment individually on these contributions in a short review such as this; they are generally lively and stimulating, although not all the articles are entirely original. Of particular interest, perhaps, is the inclusion of material on plant morphogenesis; a greater rapport between botanists and zoologists will be of considerable benefit to both. The standard of production of the book is high and it contains but few errors. In addition to the usual reference lists associated with each article, the volume contains comprehensive author- and subject-indexes.

L. J. HALE

\section{ASPECTS OF SOCIOLOGY}

Hobhouse Memorial Lectures, 1951-1960

Pp. vi +284 . (London : The Athlone Press, University of London, 1962. Distributed by Constable and Co., Ltd.) 25s. net.

$\mathrm{T}$

EN annual lectures delivered under the auspices of the Hobhouse Memorial Trust are brought together in this volume. Although at first sight there seems to be little relation between subjects ranging from the philosophy of history, through psychology and archæology to the Welfare State, a certain coherence is given to the volume as one reads on and notes from the tributes paid by the various contributors to the memory of the late Prof. L. T. Hobhouse that each reflects some facet of Hobhouse's wide interpretation of sociology. Hobhouse was one of the great pioneers in a subject which has had a hard struggle for recognition in Britain, though elsewhere, notably in the United States, it is much studied and exerts great influence.

The lectures included in this volume were delivered between 1951 and 1960. Dr. Charles Singer opens with an exceptionally well-written and stimulating account of "Technology and History", and is followed by Sir Cyril Burt on "Contributions of Psychology to Social Problems" in what is by far the longest, but probably the most outstanding, of the ten lectures, illuminating the border country where the spheres of psychology and sociology overlap. Other lectures reprinted which are concerned with problems of social change and development are those of Prof. D. M. Mackinnon "On the Notion of a Philosophy of History", Sir Aubrey Lewis on "Agents of Cultural Advance" and Sir Mortimer Wheeler on "Aspects of the Ascent of a Civilisation".

A second group of lectures deal with social policy. Prof. W. A. Robson in his lecture on the "Welfare State" argues that the aim should be to bring about conditions which, while ensuring a relatively high general level of welfare, will be such as to evoke the exceptional efforts of men and women of outstanding ability. Gunnar Myrdal, who combined the roles of professor and international civil servant, examines "Realities and Illusions in Regard to Inter-governmental Organizations", while Prof. A. Macbeath poses the question "Can Social Policies be Rationally Tested?".

The remaining two lectures do not fall readily into any classification. One is a valuable, balanced and most interesting account of "The Curious Strength of Positivism in English Political Thought" by Mr. Noel Annan, provost of King's College, Cambridge, and the other, by Mr. T. H. Marshall, discusses "International Comprehension in and through Social Science". Mr. Marshall believes that the chief need in sociology is for the deeper study of the differences which distinguish one culture from another, and would like to see comparative studies, for example, of Europe and Asia in which European and Asian sociologists collaborate, each studying both cultures.

Taken together, though their quality is somewhat uneven, the ten lectures give an excellent idea of the contributions which sociology can make to our present problems and to our knowledge of society. K. G. FENELON

\section{LARGE STRUCTURES OF HYDRAULIC ENGINEERING}

Irrigation and Hydraulic Design

By Prof. Serge Leliavsky. Vol. 3: Hydraulic Structures for Irrigation and other Purposes. Pp. xvii +765 (825 figures). (London: Chapman and Hall, Ltd., 1960.) 273s. net.

7 HIS, the third volume of the author's monumental work on irrigation and hydraulic design, is mainly concerned with the larger structures of hydraulic engineering. The first volume dealt with the hydraulic effects following the introduction of a structure into a river including seepage under structures, and the second with the planning and design of irrigation schemes and associated minor structures such as regulators, barrages and siphons. The present volume, comprising Chapters 9-13 of the whole work, discusses structures which are not necessarily connected with irrigation, but may be intended for navigation or hydraulic power production. It may therefore be of interest to a slightly different section of engineers than the second volume, and it is fortunate for such specialist readers that each chapter is largely self-contained. 